\title{
FUND OG FORSKNING \\ I DET KONGELIGE BIBLIOTEKS SAMLINGER XXXI \\ 1992
}

With summaries. Redaktion: Harald Ilsøe, John T. Lauridsen, Erik Petersen. 243 s. Ill. ISSN 0069-9896. Pris: Kr. 300,- (løssalg), kr. 200,(abonnement).

INDHOLD:

IVAN BOSERUP: Abbed Vilhelm søger råd hos pave Cølestin. Omkring den ældste danske selvbiografi (Vilh., Ep. II 47)

BJARNE SCHARTAU: 'Byzans efter Byzans' i Det kongelige Biblioteks Håndskriftsamling

GIUSEPPE MIGLIORATO: Salvator Fabris. Den italienske fægtemester og hans forbindelser med Christian IVs hof

VELLO HELK: Nogle sjældne estiske tryk og unika i Det kongelige Bibliotek og Universitetsbiblioteket

FIAMETTA PALLADINI: Esaias Pufendorfs bogsamling i Det kongelige Bibliotek

INGRID ILSØE: En københavnske bogtrykkersvend og hans arbejde i slutningen af det 18. århundrede

CARL HENRIK KOCH: Filosoffer p̊ krigsstien. Forholdet mellem Harald Høffding og Anton Thomsen belyst ud fra breve og dagbøger

INGRID ILSØE: Litteratur om dansk bogvæsen trykt 1950-1990:

Tryk, bind og boghandel ca. 1482-1920.

REGISTER til Fund og Forskning I-XXX, 1954-1991.

Årgangen er tilegnet grundlæggeren af Fund og Forskning, fhv. rigsbibliotekar Palle Birkelund i anledning af 80-årsdagen den 29. januar 1992. 